Boise State University ScholarWorks

Public Policy and Administration Faculty

Publications and Presentations

Department of Public Policy and Administration

$11-1-2017$

\title{
Overlapping Authorities in U.S. Energy Policy
}

Luke Fowler

Boise State University

Autumn T.Johnson

Boise State University

\section{(c) $\oplus \Theta \Theta$}

This is an author-produced, peer-reviewed version of this article. (C) 2017, Elsevier. Licensed under the Creative Commons AttributionNonCommercial-NoDerivs 4.0 license. http://creativecommons.org/licenses/by-nc-nd/4.0/ The final, definitive version of this document can be found online at The Electricity Journal, doi: 10.1016/j.tej.2017.09.014 


\section{Overlapping Authorities in U.S. Energy Policy}

Abstract: The authors argue overlapping intergovernmental authorities explain much of the complexities in U.S. energy policy, by accounting for limited powers, uncertain autonomy, cooperation and conflict, inter-state differences, and intersecting policies. Additionally, the authors identify implications of overlapping authority for policymakers, regulators, and industry leaders, including polycentric policymaking venues, direct and indirect policy effects, and energy system governance. Overlapping authority provides a framework for understanding intersecting roles of national, state, and local governments in energy policy.

Keywords: intergovernmental relations; policy governance; subnational government 


\section{Introduction}

Multi-layers of interdependent governments regulating U.S. energy systems create significant confusion in energy policy, where there is a lack of a comprehensive national policy, emerging state and local leadership, and dynamic markets. In response, energy policy scholarship diverges into focuses on national or subnational policies, with few attempts to integrate these into a comprehensive framework of intergovernmental regulation (Byrne, Hughes, Rickerson, and Kurdgelashvili, 2007; Osofksy and Wiseman, 2013). Consequently, there are several deficits in understanding U.S. energy governance complexities and subsequent implications for policymakers, regulators, and energy industry leaders. We argue contemporary energy policy in the U.S. is a function of overlapping authorities between national, state, and local governments, with a high degree of interdependence resulting from limitations in power, uncertain autonomy, and inter-state policy variations (Wright, 1998; Agranoff and Radin, 2014). To analyze intergovernmental relations in U.S. energy policy, we proceed in three parts: 1) a discussion of the development of intergovernmental relations, and emergence of overlappingauthority; 2) an application of these concepts to energy policy; and, 3) implications for policymakers, regulators, and industry leaders.

\section{Evolution of Intergovernmental Relations}

Intergovernmental relations in the U.S. tends to be described by one of three models, characterized by relationships between national and state governments (Wright, 1988). First, coordinate-authority (or dual or layer cake federalism) relies on independent and autonomous national and state governments, with distinct spheres of influence surrounding policies reserved 
for each level of government. Accordingly, the U.S. Supreme Court, playing referee between the national and state governments, carefully upheld "distinct, insulated spheres of national and state powers," in order to reduce intergovernmental conflict (Wright, 1988, p. 41). Specific to energy policy, states had primary authority over electricity generation, transmission, and distribution, which at the time only occurred on an intrastate scale; and the federal government was largely unconcerned with domestic energy. However, by the 1930s, the predominant model of intergovernmental relations was shifting as the U.S. developed into an industrialized society, and energy markets expanded beyond a single state. In response, Court rulings fractured the independent spheres of governments. Most notably for energy policy with Public Utility Commission of Rhode Island v. Attleboro Steam \& Electric Company (1927) and the "Attleboro Gap," in which the Supreme Court ruled that states could not regulate interstate electricity transactions. Consequently, the Attleboro ruling forced the national government to more aggressively regulate energy markets, starting with the Federal Power Act (FPA) of 1920.

Second, in response to growing policy complexity, inclusive-authority (or cooperative or marble cake federalism) relies on a system of interdependent layers of government coordinated by the national government (Wright, 1988). The Attleboro ruling was part of a wider trend in both Court ruling and national policy, where distinct national and state policy spheres were replaced with complimentary authorities (Wright, 1988; O'Toole and Christensen, 2012). Subsequently, national and state policymaking became an interdependent affair, where actions at each level are complementary and create a comprehensive policy regime lead by the national government (Wright, 1988). For energy policy, Congress designed the Federal Energy Regulatory Commission (FERC) as a central coordinator of electricity markets, and later the 
Department of Energy created further national leadership. However, states were not wholly onboard with ceding control to the federal government, leading to numerous intergovernmental conflicts (Ardoin and Grady, 2006). While the inclusive-authority model was the predominant model for most of the twentieth century, New Federalism policies that strengthened state and local political institutions, and further development of poly-centric policymaking institutions in a globalized marketplace began to erode the national-centered model of intergovernmental management (Wright, 1988; Agranoff, 2001). These broader shifts in intergovernmental relations resulted in state and local governments emerging as energy policy leaders, and creating unique roles for themselves.

Third, following these changes, Wright (1988) identified a new model of intergovernmental relations, overlapping-authority, described as:

"1) substantial areas of governmental operations involve national, state, and local units (or officials) simultaneously; 2) the areas of autonomy or single-jurisdiction independence and full discretion are comparatively small; and 3) the power and influence available to any one jurisdiction (or official) is significantly limited. The limits produce an authority pattern best described as bargaining" (p. 49).

With overlapping authority, governments retain autonomy to develop policies and management practices, but are reliant on other governments to achieve policy goals and have little power to force other institutions into complying with their leadership (Agranoff and McGuire, 1998, 2001). As such, subnational governments are more opportunistic and pursue strategic goals outside of national oversight (Conlan, 2006; McGuire, 2006). Additionally, state and local governments use their positions within the system to negotiate adjustments to federal programs that "request treatment that is not technically or apparently within standards or regulations...to redefine program goals from purely federal terms to local or at least intergovernmental terms that benefit all relevant levels of governments (Agranoff and McGuire, 2001, p. 675). Importantly, 
overlapping-authority is the intellectual basis for networks (Agranoff and Radin, 2014), where governance is predicated upon "various actors (individuals, coalitions, bureaus, and organizations) none of which possesses the power to determine the strategies of other actors" (Kickert, Klijn, and Koppenjan, 1997, p. 9). As a result, energy policy is a function of a complex interaction between federal, state, and local governments, where shared powers and mutual reliance creates a comprehensive regulatory regime for energy governance.

\section{Overlapping Authority in Energy Policy}

Overlapping authority creates unique characteristic for energy governance non-existent in previous eras of intergovernmental relations. Most notably, there are limited and dispersed powers leading to uncertain areas of autonomy and a high degree of interdependence between governments. In response to the "Attleboro Gap," Congress institutionalized a new approach to energy federalism with the Federal Power Act, and later the Natural Gas Act, which provide regulatory authority over interstate and wholesale markets to the national government, and intrastate and retail markets to state governments (DeVane, 1945; FPA, 2015). However, changes in energy markets over the following ninety years, resulted in an "expanding business of transmitting and selling electric power in interstate commerce," creating ambiguities in defining separation of powers between FERC and the states (FERC v. Electric Power Supply Association (EPSA), 2016, p. 767). Recently in Oneok v. Learjet (2015), the Court indicated the difficulty in establishing a bright line between state and national authorities in energy markets and the need for a "careful balance between federal and state regulation" (p. 1601). One key example of this is case law surrounding supposedly distinct powers of wholesale and retail markets. Currently, 
Court rulings indicate that while FERC cannot directly regulate retail sales, FERC rules can affect "substantially the quantity or terms of retail sales," as it is impossible to isolate retail and wholesale trade in contemporary electricity markets (FERC v. EPSA, 2016, p. 767).

Furthermore, "[s]tates may influence, through regulation, which generators participate in FERC's market, even though the end result may affect the wholesale market" and "FERC cannot take action that transgresses state's authority over generation, 'no matter how direct or dramatic,' the program's 'impact on wholesale rates"” (Village of Old Mill Creek v. Star, 2017, p. 25-27). As such, there is little definition between practical capacities of FERC and the states to affect both wholesale and retail electricity markets.

Consequently, both bargaining and negotiations occur as governments compete and cooperate to achieve both individual and shared policy goals. Most scholars argue there is a generally cooperative nature to intergovernmental relations in energy with both formal and informal examples (Byrne, et al., 2007; Carley, 2011; Carley and Browne, 2013; Osofsky and Wiseman, 2013). Horizontally, states form both regional and national organizations and interstate compacts to align policy goals, and there is significant evidence of inter-state information sharing, coordination of state laws, and policy distribution at state and local-levels (Freeman, 1985; Chandler, 2009; Hurlbut, 2010; Krause, 2011; Yi and Feiock, 2012; Osofsky and Wiseman, 2013; NCIC, 2017; WGA, 2017). However, there is little direct evidence of interstate or interlocal cooperation from the literature, partially as result of the interstate versus intrastate issues in energy markets where interstate cooperation falls into the realm of national authority. Although, some argue that multi-state coordinated policies amount to interstate cooperation (Bowman, 2004; Hurlbut, 2010). Vertically, regional transmission organizations 
(RTOs) "[intermix] federal, regional, state, and local lines in its institutional construction" (Osofsky and Wiseman, 2013, p. 819). Additionally, one of the key areas of multi-level cooperation is research and development. While funding and coordination of energy research is an objective of the Department of Energy's Office of Energy Efficiency and Renewable Energy (EERE), they are largely reliant on state-operated public universities, with these projects baring a direct impact on energy markets (Margolis and Kammen, 1999; Pew, 2015; DOE, 2017). Additionally, EERE funds state and local governments in developing energy plans, further cultivating a cooperative approach to energy governance (DOE, 2017).

However, emergence of state and local governments as energy policy leaders also creates vertical and horizontal competition in energy markets (Byrne, et al., 2007; Rabe, 2011; Osofsky and Wiseman, 2013). Venue-shopping from both environmental interests and industry groups perpetuates vertical competition, where political interests seek out policymaking venues that are likely to acquiesce to policy demands (Shipan and Volden, 2005; Orr, 2006; Rabe, 2008, 2013; Krause, 2011; Davis and Hoffer, 2012; Warner and Shapiro, 2013). As a result, "often the allocation of [state and national] responsibility is based on credit claiming and blame avoidance, rather than efficiency grounds" (Volden, 2005, p. 328). Furthermore, although local governments have few unique areas of regulatory authority for energy, they adapt policy when state efforts are deficient (Shipan and Volden, 2005, 2008). While scholars heavily focus upon renewable portfolio standards and net metering as key state energy policies, some local governments adopt similar policies in absence of state policy, including Aspen, CO's goal of 100\% electricity from renewable sources (Byrne, et al., 2007; DSIRE, 2017). On the other hand, horizontal competition is a new arena for inter-jurisdictional competition over citizens and 
economic development, where state and local governments use energy policy to attract jobs and capital investment, reduce energy costs, and meet citizen political preferences (Rabe, 2008, 2013; Lyon and Yin, 2010; Carley and Browne, 2013).

Due to complexities from interdependent authorities, national, state, and local governments have immense power to bargain, especially states with significant institutional capacity for energy policy implementation (Rabe, 2008). Siting is possibility the best example, where "laws and regulations for the development and siting of electric transmission projects often require reviews and/or approvals from multiple federal, tribal, state, and local entities... [and] coordination will reduc[e] redundancies and regulatory uncertainties" (Morton, 2012, p. 4). As an extension of wholesale and interstate versus retail and intrastate doctrines, FERC has regulatory authority over interstate transmission and interconnection which includes any utilityscale generation, and states over intrastate and customer-owned generation. However, FERC established guidelines for interconnection of small generators (including customer-owned) as interconnection essentially results in interstate transmission, and states have de facto authority when original transmission occurs within their jurisdiction (Osofsky and Wiseman, 2013; Chernyakhovskiy, Tian, McLaren, Miller, and Geller, 2016; DSIRE, 2017). Furthermore, other agencies also have power to affect siting, such as the Department of Defense's around military installation or the Environmental Protection Agency (EPA) for projects which impact air, water, or land quality (Morton, 2012). An array of other federal and state agencies also have potential power to affect siting decisions within their limited policy spheres (Morton, 2012). Additionally, local authority over zoning, land use, and infrastructure access, and community concerns provide further obstacles (Davis and Hoffer, 2010; Tanaka, et al., 2012). 
While not well-documented in existing literature, there is some evidence of states using their regulatory authority as a mechanism of negotiation, which is a common tool within overlapping authority (Agranoff and McGuire, 2001, 2004). In the Cross-Sound Transmission Line siting dispute, FERC approved and supported a new interstate transmission line between New York and Connecticut across Long Island Sound owned by a New York-based utility, in order to create more economic competition and supplement an older transmission line (1385 line). Arguing the new Cross-Sound Cable violated environmental regulations and with support of the utility that owned the older transmission line, Connecticut officials threatened litigation over use of the Cross-Sound Cable and passed a moratorium on new lines or expanding existing lines. Following a multi-year stalemate, “[o]nly after threatening to approve expansion of the 1385 cables, was FERC able to force the parties to the bargaining table. FERC could not preempt the states and mandate operation of the Cross-Sound transmission line, but the threat to it making a decision elsewhere led stakeholders to negotiate a settlement that allowed the line to operate" (Rossi, p. 319). The settlement included a cost-sharing agreement between the New York- and Connecticut-based utilities to replace the older line, as well as funding to remedy any environmental impacts from the new line and for Long Island Sound preservation. Rossi (2005) argues "FERC may need authority to preempt state siting laws, but absent congressional action, courts might empower state and local siting boards to take into account federal goals in competitive markets in making siting decisions" (p. 316). In either case, the current overlapping authority system provides neither enough power nor autonomy to national or state governments to make siting decisions without negotiating with the other. 
Furthermore, there is a large degree of variation in subnational policy, leading to notable interstate differences and inconsistencies across the U.S. (Byrne, et al., 2007; Rabe, 2008; Carley, 2011; Carley and Browne, 2013; Osofsky and Wiseman, 2013). Over the last few decades, states developed several unique policy tools that tend to fall into one of three categories: demand-side financial incentives for end-users; supply-side regulatory policies for generators; or, a mixture of both (DSIRE, 2017). Adding further nuance, several states have very active local governments developing their own policies, while local governments in other states avoid energy policy entirely (Byrne, et al., 2007). Carley (2011) contends interstate differences are based on motivates to diversify, decentralized, and decarbonize energy portfolios, which are connected to state socio-economic and political characteristics. Other scholars argue inter-state variations are related to intergovernmental competitive pressures, local political preferences, and resource availability (Matisoff, 2008; Chandler, 2009), which further highlights complex relationships for subnational governments in energy governance. Additionally, Fowler (2015) suggests states take on different approaches to energy management, with states treating energy as utility regulations, economic development, environmental protection, or with no coordinated strategy. Nevertheless, there is still significant debate on impacts of subnational policy and management on energy markets, with some scholarship noting cases of success and some finding systematic failure in national analyses (Byrne, et al., 2007; Carley, 2009, 2011).

Finally, overlapping authority creates policy overlaps, where governments at different levels operate programs affecting the same economic activities (Wright, 1988). Possibly the best example is financial incentives, with the Database for State Incentives for Renewables and Efficiency (DSIRE) listing 18 national programs, 416 state programs in all 50 states, and 80 local 
programs across 63 local governments in 22 states aimed at encouraging different renewable energy production and consumption behaviors. Financial incentives are particularly appealing as "they reduce the cost of alternative technologies (i.e., provide a "carrot"), but do not explicitly raise the cost of conventional technologies (i.e., use a "stick")" (Carley, 2011, p. 276). Furthermore, national, state, and local governments are also employing goals and standards for energy use in public buildings and green power purchasing agreements (EPA, 2017a, 2017b; DSIRE, 2016). Consequently, a citizen or utility can be simultaneously affected by policies from national, state, and local sources that are uncoordinated but similar. As a consequence of the complexities of overlapping authority, energy policy is not coordinated by any single entity; instead it is subject to a multi-level governance scheme that provides actors at national, state, and local-levels opportunities to impact energy systems.

\section{Implications for Energy Policy}

Overlapping authority has three important implications for energy policy. First, policymaking is not unilateral, and requires negotiation and collaboration. National, state, and local governments all have substantial power to affect energy systems, providing opportunity to negotiate and bargain to meet strategic goals. Mechanisms of negotiation come in many forms, but when negotiation fails, it leads to conflict, fractured governance regimes, and institutional roadblocks for energy systems (Markell, 2000; Agranoff and McGuire, 2001, 2004; Rossi, 2005). Nevertheless, polycentric policymaking also provide both industry and environmental advocacy groups opportunities for venue shopping (Orr, 2006; Rabe, 2008, 2013; Krause, 2011; Davis and Hoffer, 2012). When political institutions at one level do not to adequately address 
failures in energy systems, there is recourse at other levels of government. Thus, it is advantageous for policymakers, regulators, and industry leaders to understand that there is no single arena for energy policymaking.

Furthermore, in complex environments, policymakers and public managers find significant benefit from collaborating with counterparts in other public and private organizations. Previous scholarship indicates collaboration reduces inter-organizational transaction costs by decreasing uncertainty, coordinating efforts, and enhancing capacity and resources (Clingermayer and Feiock, 1997; Brown and Potoski, 2003; McQuaid, 2010; Provan and Lemaire, 2012; O'Toole, 2015). Consequently, overlapping authority requires interorganizational collaboration to achieve shared policy goals, or energy systems will be plagued with bureaucratic and institutional limitations. However, energy leaders should be wary of expanding governance networks too far, as they suffer from "operational, performance, or legal barriers that prevent the next action step... [and] face challenges in converting solutions into policy energy, assessing internal effectiveness, surmounting the inevitable process blockages, mission drift, and so on" (McGuire and Agranoff, 2011, p. 265). Furthermore, networks eventually become overburden by coordination costs, leading to "overprocessing" and “collaborative inertia" (McGuire and Agranoff, 2011; Provan and Lemaire, 2012).

Second, there are many sources of regulation that are both direct and indirect. As Court rulings discussed above indicate, national and state governments have supposedly distinct spheres of regulatory authority, but are not barred from having an indirect substantive impact outside of their sphere. Therefore, crafty institutions can have much bigger footprints in energy regulation than legal authorities would suggest. A good example is local governments who have 
no official authority to regulate transmission or generation siting, but use local zoning and planning authority to substantially impact siting decisions (Davis and Hoffer, 2010). Thus, policy actors must be aware of both formal limitations to power and potential indirect impacts of policies on energy systems, which provide substantial potential to create obstacles for others. Consequently, indirect effects of policy are just as important as direct effects for energy systems.

Finally, there is a big difference between governance and policy implementation. While policy implementation is "the carrying out of a basic policy decision... [which] identifies the problem(s) to be addressed, stipulates the objective(s) to be pursued, and in a variety of ways, 'structures' the implementation process” (Mazmanian and Sabatier, 1983, pgs. 20-21), governance is the exercise of power by both state and non-state organizations and includes the full gambit of functions required to produce public goods and services (Olowu 2002). Importantly, network governance emerged from overlapping intergovernmental authorities (Agranoff and Radin, 2014). There is no single piece of legislation or court ruling or executive order that dictates how energy systems are regulated; rather there is a montage of overlapping, competing, and complementary policies that taken together create a governance regime that shapes energy systems in the U.S. Therefore, energy governance transcends singular public policies and subsequent implementation, and is a product of entire policy processes that include institutions within and outside of government. It is incumbent on policymakers, regulators, and industry leaders to consider shared policy goals, where mutually desirable outcomes take precedent over organizational missions and lead to strategic collaborations and comprehensive regulatory regimes (Lynn, Heinrich, and Hill, 2001; Hill and Hupe, 2006). 


\section{Conclusions}

Numerous scholars lament the lack of a comprehensive U.S. energy policy, where national, state, and local governments adopt disparate and uncoordinated policies (Byrne, et al., 2007; Rabe, 2008, 2011; Osofsky and Wiseman, 2013). However, seemingly incomprehensive energy policy results from overlapping intergovernmental authorities, which complicate energy governance through limited powers, uncertain autonomy, alternating intergovernmental competition and cooperation that lead to negotiating and bargaining, interstate differences in policy and management, and intersecting policies (Wright, 1988; Agranoff and Radin, 2014). Consequently, governments pursue strategic interests but are reliant on other governmental actors to achieve shared policy goals, so it is nearly impossible to disentangle national, state, and local energy policies from each other. Overlapping authority creates a unique situation in energy governance that is very different from past approaches and conventional policy processes. For policymakers, regulators, and industry leaders, overlapping authority means: there are multiple policymaking venues with no single entity having the authority to unilaterally control energy systems; policies shape energy system both directly and indirectly, with informal authorities just as important as formal authorities; and, energy governance incorporates multiple policies, processes, and institutions. While many energy policy actors learn these implications first-hand, the overlapping-authority model provides depth and explanation. Subsequently, Wright's (1988) work on overlapping-authority and subsequent scholarship (Cho, Kelleher, Wright, and Yackee, 2005; Agranoff and Radin, 2014; Burke, 2014) creates important analytical tools for understanding U.S. energy governance in comprehensive terms, by providing a guide to intergovernmental relations in a complex institutional environmental. 


\section{References}

Agranoff, R. 2001. Managing within the Matrix: Do Collaborative Intergovernmental Relatives Exist? Publius 31(2): 31-56.

Agranoff, R. and M. McGuire. 1998. A Jurisdiction-Based Model of Intergovernmental Management in U.S. Cities. Publius 28(4): 1-20.

Agranoff, R. and M. McGuire. 2001. American Federalism and the Search for Models of Management. Public Administration Review 61(6): 671-681.

Agranoff, R. and M. McGuire. 2004. Another Look at Bargaining and Negotiating in Intergovernmental Management. Journal of Public Administration Research \& Theory 14(4): 495-512.

Agranoff, R. and B.A. Radin. 2014. Deil Wright's Overlapping Model of Intergovernmental Relations: The Basis for Contemporary Intergovernmental Relations. Publius 45(1): 139159.

Ardoin, P.J. and D. Grady. 2006. The Politics of Electricity Restructuring across the American States: Power Failure and Policy Failure. State \& Local Government Review 38(3): 165175.

Bowman, A.O’M. 2004. Horizontal Federalism: Exploring Interstate Interactions. Journal of Public Administration Research \& Theory 14(4): 535-546.

Brown, T.L. and M. Potoski. 2003. Transaction Costs and Institutional Explanations for Government Service Production Decisions. Journal of Public Administration Research \& Theory 13(4): 441-468. 
Burke, B.F. 2014. Understanding Intergovernmental Relations, Twenty-five Years Hence. State \& Local Government Review 46(1):63-76.

Byrne, J., K. Hughes, W. Rickerson, and L. Kurdgelashvili. 2007. American Policy Conflict in the Greenhouse: Divergent Trends in Federal, Regional, State, and Local Green Energy and Climate Change Policy. Energy Policy 35(9): 4555-4573.

Carley, S. 2009. State Renewable Energy Electricity Policies: An Empirical Evaluation of Effectiveness. Energy Policy 37(8): 3071-3081.

Carley, S. 2011. The Era of State Energy Policy Innovation: A Review of Policy Instruments. Review of Policy Research 28(3): 265-294.

Carley, S. and T.R. Browne. 2013. Innovative U.S. Energy Policy: A Review of States' Policy Experiences. Wiley Interdisciplinary Reviews: Energy and Environment 2(5): 488-506.

Chandler, J. 2009. Trendy Solutions: Why Do States Adopt Sustainable Energy Portfolio Standards? Energy Policy 37(8): 3274-3281.

Chernyakhovskiy, I., T. Tian, J. McLaren, M. Miller, and N. Geller. 2016. U.S. Laws and Regulations for Renewable Energy Grid Interconnections. National Renewable Energy Laboratory. Technical Report NREL/TP-6A20-66724. https://www.nrel.gov/docs/fy16osti/66724.pdf [Retrieved August, 9, 2017]

Clingermayer, J. and R.C. Feiock. 1997. Leadership Turnover, Transaction Costs, and External City Service Delivery. Public Administration Review 57(3): 231-239.

Cho, C., C.A. Kelleher, D.S. Wright, and S.W. Yackee. 2005. Translating National Policy Objectives into Local Achievements across Planes of Governance and among Multiple 
Actors: Second-Order Devolution and Welfare Reform Implementation. Journal of Public Administration Research \& Theory 15(1): 31-54.

Conlan, T. 2006. From Cooperative to Opportunistic Federalism: Reflections on the HalfCentury Anniversary of the Commission on Intergovernmental Relations. Public Administration Review 66(5): 663-676.

Database for State Incentives for Renewables and Efficiency (DSIRE). 2017. Programs. North Carolina Clean Energy Technology Center. http://programs.dsireusa.org/system/program [Retrieved August 10, 2017]

Davis, C. and K. Hoffer. 2010. Energy Development in the U.S. Rockies: A Role for Counties. Publius 40(2): 296-311.

Davis, C. and K. Hoffer. 2012. Federalizing Energy? Agenda Change and the Politics of Fracking. Policy Sciences 45(3): 221-241.

Devane, D.A. 1945. Highlights of Legislative History of the Federal Power Act of 1935 and the Natural Gas Act of 1938. George Washington Law Review 14(1).

FERC v. Electric Power Supply Association (EPSA), 136 S.Ct. 760 (2016).

Federal Power Act, 16 U.S.C. § 824 (2015).

Fowler, L. 2015. Management Matters in Renewable Portfolio Standards. International Journal of Organization Theory and Behavior 18(2): 206-230.

Freeman, P.K. 1985. Interstate Communication among State Legislators regarding Energy Policy Innovation. Publius 15(4): 99-111.

Hill, M. and P. Hupe. 2006. Analysing Policy Processes as Multiple Governance: Accountability in Social Policy. Policy and Politics 34(3): 557-573. 
Hurlbut, D.J. 2010. Multistate Decision Making for Renewable Energy and Transmission: An Overview. Colorado Law Review 81: 677-703.

Kickert, W.J.M., E. Klijn. And J.F.M. Koppenjan. 1997. Introduction: A Management Perspective on Policy Networks. In Managing Complex Networks, edited by W.J.M. Kickert, E. Klijn, and J.F.M. Koppenjan, 1-13. London: Sage Publications.

Krause, R.M. 2011. Policy Innovation, Intergovernmental Relations, and the Adoption of Climate Protection Initiatives by U.S. Cities. Journal of Urban Affairs 33(1): 45-60.

Lynn, L.E., C.J. Heinrich, and C.J. Hill. 2001. Improving Governance. Washington, DC: Georgetown University.

Lyon, T.P. and H. Yin. 2010. Why Do States Adopt Renewable Portfolio Standards?: An Empirical Investigation. The Energy Journal 31(3): 133-157.

Markell, D.L. 2000. The Role of Deterrence-Based Enforcement in a 'Reinvented' State/Federal Relationship: The Divided between Theory and Reality. Harvard Environmental Law Review 24(1): 1-114.

Matisoff, D.C. 2008. The Adoption of State Climate Change Policies and Renewable Portfolio Standards: Regional Diffusion or Internal Determinants? Review of Policy Research 25(6): 527-546.

Mazmanian, D.A. and P.A. Sabatier. 1983. Implementation and Public Policy. Glenview, IL: Scott/Foresman.

McGuire, M. 2006. Intergovernmental Management: A View from the Bottom. Public Administration Review 66(5): 677-679. 
McQuaid, R.W. 2010. Theory of Organizational Partnerships. In The New Public Governance? Emerging Perspectives on the Theory and Practice of Public Governance edited by S.P. Osborne, 127-148. New York: Routledge.

Morton, L. 2012. Interagency Activities Related to Siting and Permitting. Office of Energy Efficiency and Renewable Energy. U.S. Department of Energy. https://energy.gov/sites/prod/files/2015/07/f25/June\%2028\%20\%20Renewable\%20Energy\%20at\%20DOE\%20-\%20Morton_0.pdf [Retrieved August, 8, 2017].

National Center for Interstate Compacts (NCIC). 2017. National Center for Interstate Compacts Database. http://apps.csg.org/ncic/ [Retrieved January 25, 2017].

Olowu, D. 2002. Introduction - Governance and Public Administration in the $21^{\text {st }}$ Century: A Research and Training Prospectus. International Review of Administrative Sciences 68(3): 345-353.

Oneok v. Learjet, 135 S.Ct. 1591 (2015).

Orr, S.K. 2006. Policy Subsystems and Regimes: Organized Interests and Climate Change Policy. Policy Studies Journal 34(2): 147-169.

Osofsky, H.M. and H.J. Wiseman. 2013. Dynamic Energy Federalism. Maryland Law Review 72(3): 773-843.

O’Toole, L.J. 2015. Networks and Networking: The Public Administrative Agendas. Public Administration Review 75(3): 361-371.

O’Toole, L.J. and R.K. Christensen. 2012. American Intergovernmental Relations: Foundations, Perspectives, and Issues, $5^{\text {th }}$ ed. Thousand Oaks, CA: CQ Press. 
Provan, K.G. and R.H. Lemaire. 2012. Core Concepts and Key Ideas for Understanding Public Sector Organizational Networks: Using Research to Inform Scholarship and Practice. Public Administration Review 72(5): 638-648.

Public Util. Comm. Of R.I. v. Attleboro Steam \& Elec. Co., 273 US 83 (1927).

Rabe, B. 2008. States on Steroids: The Intergovernmental Odyssey of American Climate Policy. Review of Policy Research 25(2): 105-128.

Rabe, B. 2011. Contested Federalism and American Climate Policy. Publius 41(3): 494-521.

Rabe, B. 2013. Racing to the Top, Bottom, or the Middle of the Pack? The Evolving State Government Role in Environmental Protection. In Environmental Policy: New Directions for the Twenty-First Century, edited by N.J. Vig and M.E. Kraft, 30-53. Washington, DC: CQ Press.

Rossi, J. 2005. Transmission Siting in Deregulated Wholesale Power Markets: Re-Imagining the Role of Courts in Resolving Federal-State Siting Impasses. Duke Environmental Law \& Policy Forum 15: 315-339.

Shipan, C., and C.M. Volden. 2005. Diffusion, Preemption, and Venue Shopping: The Spread of Local Antismoking Policies. Scholars in Health Policy Research Program Working Papers Series-31. Princeton, NJ: Robert Wood Johnson Foundation.

Shipan, C., and C.M. Volden. 2008. The Mechanisms of Policy Diffusion. American Journal of Political Science 52(4): 840-857.

Tanaka, A.M, P.C. Anastasopoulos, N. Carboneau, J.D. Fricker, J.A. Habermann, and J.E. Haddock. 2012. Policy Considerations for Construction of Wind Farms and Biofuel Plant Facilities. State \& Local Government Review 44(2): 140-149. 
U.S. Department of Energy (DOE). 2017. EERE Initiatives and Projects. Office of Energy Efficiency and Renewable Energy. https://energy.gov/eere/about-us/initiatives-andprojects [Retrieved August, 9, 2017].

U.S. Environmental Protection Agency. 2017a. Green Power Partnership Top 30 Local Government. https://www.epa.gov/greenpower/green-power-partnership-top-30-localgovernment [Retrieved August, 9, 2017]

U.S. Environmental Protection Agency. 2017b. Guide to Purchasing Green Power. https://www.epa.gov/sites/production/files/201601/documents/purchasing_guide_for_web.pdf [Retrieved August, 9, 2017] Village of Old Mill Creek v. Star, No. 17 CV 1163, slip op. (N.D. Ill. July 14, 2017); EPSA v. Star, No. 17 CV 1164, slip op. (N.D. Ill. July 14, 2017).

Volden, C. 2005. Intergovernmental Political Competition in American Federalism. American Journal of Political Science 49(2): 327-342.

Warner, B. and J. Shapiro. 2013. Fractured, Fragmented Federalism: A Study of Fracking Regulatory Policy. Publius 43(3): 474-496.

Western Governors Association (WGA). 2017. Policy Resolution 2016-09: Energy and Transmission. http://westgov.org/resolutions/energy-and-transmission [Retrieved August $8,2017]$

Wright, D.S. 1988. Understanding Intergovernmental Relations, $3^{\text {rd }}$ edition. Belmont, CA: Wadsworth, Inc.

Yi, H. and R.C. Feiock. 2012. Policy Tool Interactions and the Adoption of State Renewable Portfolio Standards. Review of Policy Research 29(2): 193-206. 